\title{
RETRACTED ARTICLE: Women's Narratives of Marital and Divorce Issues and Impact on their Health
}

\section{Komal Niazi ${ }^{1}$ (D) $\cdot$ Guoqiang $\mathrm{He}^{1} \cdot$ Waheed Chaudhry ${ }^{2} \cdot$ Tahir Mumtaz Awan $^{3} \cdot$ Shakir Ullah ${ }^{1}$}

Published online: 17 December 2018

(C) Springer Science+Business Media, LLC, part of Springer Nature 2018

The Editor-in-Chief has retracted this article [1] because it contains material that substantially overlaps with the following articles [2-4].

All authors agree to this retraction.

\section{References}

[1] Niazi, K., He, G., Chaudhry, W. et al. Women's Narratives of Marital and Divorce Issues and Impact on their Health. J Relig Health (2018). https://doi.org/10.1007/s10943-018-00741-2

[2] Agha, N. Kinship in rural Pakistan: Consanguineous marriages and their implications for women. In Women's Studies International Forum 2016 Jan 1 (Vol. 54, pp. 1-10). Pergamon. https://doi.org/10. 1016/j.wsif.2015.10.005

[3] Falconer, E. Telling tales: A feminist interpretation of women's travel narratives. Enquire. 2009 Jun;2(1):21-40. https://www.nottingham.ac.uk/sociology/documents/enquire/vol-2-issue-1-falconer.pdf

[4] Effects of Divorce on Children's Health. Marripedia. http://www.marripedia.org/effects_of_divorce_on_ children_s_health

Electronic supplementary material The online version of this article (https://doi.org/10.1007/s10943-01800741-2) contains supplementary material, which is available to authorized users.

Komal Niazi

niazi.komal_leo@yahoo.com; niazi@mail2.sysu.edu.cn

1 School of Sociology and Anthropology, Sun Yat-Sen University, No. 135 Xingang West Road, Guangzhou 510275, People's Republic of China

2 Department of Anthropology, Quaid-i-Azam University, Islamabad 45320, Pakistan

3 Department of Management Sciences, COMSATS University Islamabad, Park Road, Tarlai Kalan, Islamabad 45550, Pakistan 